\title{
Beyond the Blank Cheque: Arming Iran during the Ford Administration
}

\author{
Stephen McGlinchey \& Andrew Moran
}

\begin{abstract}
To cite this article: Stephen McGlinchey \& Andrew Moran (2016) 'Beyond the Blank Cheque: Arming Iran during the Ford Administration', Diplomacy \& Statecraft, 27:3, 523544.
\end{abstract}

To link to this article: http://dx.doi.org/10.1080/09592296.2016.1196074

Prior to the Iranian Revolution in 1979, the United States and Iran enjoyed a close alliance built around almost three decades of American support for Iran's pro-Western monarch, Shah Mohammed Reza Pahlavi. The Shah's desire for military supremacy over his neighbours and his distrust of the Soviets saw him seek a military relationship with the United States following the end of the Second World War. This relationship began as a minor aid programme in 1950 before undergoing a step change with the Anglo-American coup in Iran in 1953 that unseated a left-leaning popularly elected coalition that had marginalised the Shah. Following the coup, Iran's military aid was renewed, upgraded, and later supplemented by arms credit purchases in the early 1960s. By 1968 Iran was America's largest single arms customer, purchasing approximately US\$150 million of arms annually. In 1972, following a meeting in Tehran with President Richard Nixon and his national security advisor, Henry Kissinger, Iran received a "blank cheque" to purchase any arms it desired on favourable credit terms - except for nuclear weapons. Within days of the meeting, the Shah embarked on an annual multi-billion dollar arms spending spree in Washington, transforming the Iranian-American arms relationship qualitatively and quantitatively. That transformation endured until late 1978 when the Shah began to lose control of his domestic affairs and indicated to the new president, Jimmy Carter, that he would need to delay any further programmes.

As Iranian-American arms sales grew ever grander through the 1970s and the power of the executive in the United States reached a nadir following Richard Nixon's resignation over the Watergate scandal, his Republican successor's, Gerald Ford's, time in office became a pivotal and testing period for Iranian-American relations. However, the relatively small amount of dedicated historiography on the Ford period barely mentions Iran at all. ${ }^{1}$ On the other hand, studies that address Iran throughout the 1970s often only mention the Ford years in passing or omit analysis of the Administration's two and one- half years in office entirely. ${ }^{2}$ These omissions are in no doubt due to the significance and impact of Nixon's tenure, both in general terms - and in this case, in reference to Iranian-American policy. 
When Nixon came to power in January 1969, he developed a doctrine in response to the escalating human and political cost in the Vietnam War. In essence, his doctrine sought to transfer the costs of Cold War containment and essentially outsource it. In that sense, the Nixon Doctrine's logic was to encourage certain more capable allies to pay for their own defences, rather than rely on direct American force projection and military aid in global containment. In Iran's case, a capable ally willing to pay for its own arms, the Doctrine fuelled the thinking behind the blank cheque policy - a policy devolving from meetings between Nixon and the Shah of Iran at Tehran in May 1972. ${ }^{3}$ The Doctrine was a neat fit for the Shah thanks to his rising oil revenues and ambitions to establish Iran as a peerless power in the Gulf, or as he often referred to it - the Japan of West Asia. Throughout the 1960s, the Gulf and the wider Middle East had become a major concern for American policy-makers. The list of American allies had become scarce due to Washington's growing support for Israel and the volatility of Arab nationalism. When the British announced that they were retreating East of Suez and would be withdrawing their military forces from of the Gulf by the end of 1971 due to dire economic conditions and overstretched commitments overseas, Nixon looked to the Shah to play the major part in preventing any post-British vacuum allowing the Soviets to step in. The major arms relationship with Iran twinned with a deep economic accord with Saudi Arabia and tentative relations with the smaller Powers in the area. Having Iran's arms sales facilitated in America was good for Cold Wargeopolitics; it fully locked the Shah into the American orbit following a brief flirtation with the Soviets over high-level arms purchases in the 1960s, and it was good for the American economy. Hence, it was vital for Nixon's post-1972 plan for the Gulf to allow Iran to build up its forces to the level the Shah deemed necessary without political interference in Washington - a build up that was only in its first phase when Ford took office in August 1974.

Whilst the extant literature has largely missed Iran during the Ford years, much needs consideration. Between 1974 and 1976, significant developments in the U.S-Iran arms relationship occurred. It is largely a story of continuity from the legacy bestowed by Nixon's blank cheque agreement - but it is also a story of a deepening, and increasingly complex, relationship. That deepening presented a series of challenges for the Ford Administration. As the various arms developments unfolded during 1974 and 1975, there was a noteworthy under-current developing initiated by concerns at the Department of Defense and, in Congress, over ever-closer American military entanglement in Iran. Arms sales were not just a matter of making a transaction and receiving money in return for the supply of goods. The Iranians required training to operate the equipment, some of which was the most advanced in the American inventory. As arms sales to Iran spiralled to levels that surpassed those with any other Power, there was an understandable tension within the Pentagon to ensure that such a large deployment of American equipment - mere miles from the Soviet southern border - was safe. Through the same period, Congress had begun to express similar concerns, making tentative moves to establish an independent position on arming Iran. Both examples eventually combine to offer an insight into the challenges that Ford faced regarding arming Iran and yield new insights into the 
importance of the decisions Ford made on the larger Iranian-American relationship.

\section{The Congressional Challenge}

The context in which Ford became president is important. Nixon's resignation propelled Ford into office by virtue of him having already replaced the disgraced Spiro Agnew as vice-president. Prior to this, Ford had been a member of the House of Representatives for over two decades - eight as Minority Leader. It would be no exaggeration to say that his heart was in the Congress, as both he and many others have remarked. ${ }^{4}$ With Nixon removed from power, it appeared that Congress would be more receptive to Ford as a former colleague. Ford hoped this would be the case. In his first presidential address to Congress on 12 August 1974, he made clear that he wanted to end the antagonism and conflict that had marked the relationship between the executive and Congress during the Nixon years, proclaiming as his motto

. . communication, conciliation, compromise and co-operation. This Congress . . . will be my working partner as well as my most constructive critic . . . I I do not want a honeymoon with you. I want a good marriage. ${ }^{5}$

This hope was quickly shattered by Ford's controversial pardon of Nixon, which led his assistant for legislative affairs, Max Friedersdorf, to comment that the euphoria of Nixon's resignation was "quickly dissipated with the pardon", adding that "after the pardon I don't think we had a marriage ... I would say it was an uneasy separation. It certainly was not a marriage". 6

Part of Ford's problem was that the Watergate revelations and the Vietnam War had seriously damaged the faith of millions of Americans in the federal government, the presidency, and in the constitutional process itself. The balance of power that many analysts believed had moved towards "the imperial presidency" ${ }^{7}$ under the Democrat Lyndon Johnson and the Republican Nixon had begun to shift from the executive to the legislature as Congress, dominated by Democrats, sought to re-assert its authority in both foreign and domestic policy and fill the vacuum created by the ailing Nixon Administration. Furthermore, the hopes of the legislative ambitions articulated in John F. Kennedy's "New Frontier" (1961-1963) and Johnson's "Great Society" (1965-1968) had crumbled as the American people faced double-digit inflation, rising unemployment, an energy crisis, a plunging stock market, deadlock in the Strategic Arms Limitation Talks with the Soviets, and the closing trauma of Vietnam.

Ford was unusually handicapped in facing these difficulties. As an un-elected president, he had to tackle these challenges without a national mandate. He had never run for national or even state-wide office. In fact, his only electoral experience was as the Congressman for the Fifth District of Michigan, which he had represented since 1949. Sensing weakness, Congress set upon opposing Ford's various early economic, domestic taxation, and benefits bills - even to the extent of overturning several presidential vetoes - an experience that caused Ford deep personal upset. ${ }^{8}$ Therefore, having Congress 
prove such a crippling obstacle in virtually every exercise of government was disorienting for him.

Ford, however, assumed the presidency "confident that [he] knew as much about foreign policy as any member of Congress". ${ }^{9}$ He had travelled abroad extensively, served on both the House Defense Appropriations Sub-committee, where he became the leading Republican expert on the defence budget, and the House Foreign Operations Appropriations Sub-committee. Henry Kissinger, Nixon's secretary of state and national security advisor, or Kissinger's National Security Council [NSC] deputy, Brent Scowcroft, had also briefed him every week during his eight months as vice-president. ${ }^{10}$ To project an image of stability and continuity in foreign affairs at a time of tremendous upheaval, Ford retained Kissinger in his two positions. This also reflected his "admiration" for Kissinger. "I respected his expertise in foreign policy", he later wrote. "He was a total pragmatist who thought in terms of power and national interest instead of ideology. He had a global view of international relationships and tried to rearrange them in a way that would be beneficial to the United States". ${ }^{11}$

In the early days of his presidency, Ford relied on Kissinger but, as he got to grips with the intricacies of international relations and gained in confidence, he occasionally rejected his advice. In October 1974, for example, despite Kissinger's objections, he signed a compromise continuing appropriations resolution that required a cut-off of military aid to Turkey. ${ }^{12}$ More dramatically, they were to come to blows over America's policy in Southeast Asia. Both, however, shared a similar view of Russia's involvement in the Middle East, with Ford convinced that the Soviet Union was seeking "to keep the pot boiling in that part of the world". ${ }^{13}$ They were all too aware, as was the Shah, that Russia had influence in Iraq.

In the dying days of Nixon's Administration, Congress grew increasingly concerned by the rapidly increasing amount of arms sales to Iran. Most notably, Iranian purchasing jumped from approximately US $\$ 150$ million annually in 1971 to a figure around US\$3 billion in 1973. Not surprisingly, Congress was motivated to investigate. A legacy of Nixon in this respect was his systematic removal of effective arms sale oversight from Congress to facilitate Nixon Doctrine policies. With the imperial presidency now over, a momentum was underway in Congress to recover lost influence.

The Senate Foreign Relations Committee despatched Senators J. Norvill Jones and George W. Ashworth to Tehran in late October 1974 to conduct a report. The senators embarked without any prior disclosure to the American Embassyin Tehran as to the exact nature of their mission. ${ }^{14}$ The State Department learnt of the trip on the same day as the ambassador to Iran, Richard Helms, via an eleven-point memorandum noting that the senators would be conducting a comprehensive investigation of Iranian-American policy. It would range from the ability of Iran to absorb sophisticated American equipment, the wisdom of the ever-increasing number of American armed personnel and private contractors in Iran, and concerns over potentially illegal transfers of American equipment 
from Iran to other nations such as Oman and Pakistan. ${ }^{15}$ Helms acted quickly, targeting a letter to Democratic Senator Stewart Symington who had led a series of Congressional hearings into arms sales in 1967 following the Six Day War and a revisionist on arms issues. Going on Symington's past record, Helms suspected him to be the anti-Iran ringleader in the Committee and set about stressing the positive impact that Iranian arms sales were having on the troubled American economy. Helms wrote:

The idea that the United States should beat up on Iran because of high crude oil prices is childish and short-sighted. Are we not a capitalist country which depends on proceeds from industry to provide the taxes to pay for salaries in the Congressional Branch as well as the Executive? ${ }^{16}$

Two weeks later, discussing the matter at a meeting in the State Department with Scowcroft and James Schlesinger, the secretary of Defense, Kissinger reaffirmed Helms' case: "The Shah is the one guy who has a strategic conception. He is with us on everything but oil and there he only wants money - and he could put US $\$ 10$ billion into the U.S. [economy]". ${ }^{17}$ Upon returning to Washington, the two senators raised various concerns in their draft report that caused the Foreign Relations Committee, spearheaded by the Democratic senator, William Fulbright, to press the Ford Administration hard for access to classified documents on the landmark 1972 arms sales agreed between the Shah and Nixon. ${ }^{18}$ It included the tentative discussions of the sale of Laser-guided bombs and F-14 and $\mathrm{F}-15$ fighter jets. ${ }^{19}$ Fulbright's request came on top of a similar request from Democratic Congressman Clarence D. Long, who had asked for permission in a letter to Kissinger on 16 October 1974 to conduct research on classified material on American arms sales to Iran. ${ }^{20}$ Clearly, there was an appetite on Capitol Hill for information on Iranian-American arms sales, information the Administration withheld. Kissinger's NSC staff, together with his deputy secretary at the State Department, Robert S. Ingersoll, recommended in mid-December that both Fulbright and Long review such documents, with an NSC staff officer made available to explain any queries that the Congressional staff raised upon consulting them. ${ }^{21}$ Presumably, this would allow for managing the situation without rejecting the enquiries wholesale. Kissinger denied this request on 13 December, noting on a memorandum that he preferred purposefully to stall the issue and ignore the requests - hoping that the issue would pass. ${ }^{22}$ In the internal discussion within the NSC, the main areas of sensitivity revolved around the blank cheque on arms sales that Nixon had issued to the Shah, detailed explicitly on one of the documents Fulbright had requested. As the Administration denied Congress and the public knowledge about the blank cheque, speculation had taken hold in lieu of full disclosure of the facts. For that reason, Kissinger's sensitivity was understandable. ${ }^{23}$

Kissinger's opposition to Congressional meddling in foreign policy remains well documented - something he had regularly voiced publicly throughout 1974 and 1975. In a late January 1975 speech, he reaffirmed that Congress was "not well suited to the detailed supervision of the day-to-day conduct of diplomacy". ${ }^{24}$ Unfortunately for Kissinger, the trend was clearly moving toward Congress exercising the full extent of its constitutional oversight role, in the spirit of Democratic Senator Frank Church's idiom that the Congress should not conduct foreign policy - but it should actively help in making it. ${ }^{25}$ Hence, 
Kissinger's denial of access to the Iran-arms papers in December 1974 did not end the matter. It caused frequent back and forth acrimony throughout the remainder of the Ford years as Kissinger continued to fend off further Congressional attempts to access classified arms documents. ${ }^{26}$

In the final days of 1974, Ford faced increasing difficulties with Congress, not least because of the fall-out of his controversial pardon of Nixon, heavy Republican loses in the mid-term elections, and an economy plummeting into recession. The passing of the Foreign Assistance Act highlighted the growing challenges from Congress. The Act contained an amendment added by Senator Gaylord Nelson and Representative Jonathan Bingham - both Democrats -that mandated that any arms sale in excess of US\$25 million required Congressional approval. ${ }^{27}$ Consequently, Congress would receive notification of such sales and over a period of 20 days decide to authorise or block the transfer. Blocking could only occur by a concurrent resolution from both Houses of Congress. Therefore, if one House passed the sale, it would proceed. The Nelson-Bingham amendment would have major ramifications for arms policy, and would - if exercised - effectively kill the blank cheque policy towards Iran.

Now armed with new powers, Congress continued to seek its own perspective. Another team went to Iran, Kuwait, and Saudi Arabia on 22 May 1975 to investigate further American arms sales. Largely passive, the ensuing report did not recommend any clear action - instead lamenting that there appeared to be no discernible policy on arms supplies, rather an ad hoc approach that lacked co-ordination and oversight. ${ }^{28}$ These conclusions reaffirmed earlier perceptions by the Congress that it did not understand the exact terms with which the Administration was carrying out its arms sales policy towards Iran. One can only surmise that Kissinger's continued denial of co-operation with Congress, principally his withholding of the arms documents that had been frequently requested, had limited the scope of their understanding. The essential controversy that the Administration was attempting to contain was that a foreign leader was essentially conducting arms purchases in an unmoderated fashion, with absolutely no safeguards or intervention by American governmental agencies - with the exception of sales involving nuclear technology. ${ }^{29}$ Historically this was an aberration in American policy. Yet, it was the centrepiece of the unique United States relationship with the Shah - who by 1972 had become the only regional ally truly compatible with Nixon Doctrine because, first, he was willing and able and, second, not wholly antagonistic to the other regional Powers when viewed in relation to Israel, for example. Hence, the Shah had manoeuvred himself into a position where he was punching far above his weight due to Cold War geopolitics.

The extent of the secrecy within the executive going back to 1972 had thus far arrested the efforts of Congress to come to terms with the Nixon-Ford-Kissinger policy orientation towards Iran and understand why arms sales in this case were so different from those with other allies. To that effect, calling the hearings on Capitol Hill that followed through June and July 1975 came with the purpose of finally providing Congress with that very understanding. During the first series of hearings, the despatch of officials at the deputy 
and under-secretary levels from the departments of State and Defense occurred to placate further the Congress with limited disclosures. ${ }^{30}$ Unsatisfied with that testimony, the Committee on Foreign Relations bypassed any possibility of lower level Administration officials fobbing it off and summoned Kissinger directly as part of a series of further hearings. ${ }^{31}$ Kissinger duly testified before the Senate Foreign Relations Committee on 25 July 1975. Consuming "considerable time", discussion of Iran's potential purchase of the cutting edge - and at that time still in development - air surveillance Airborne Warning and Control System [AWACS] raised significant questions, ${ }^{32}$ Kissinger cabled a message to the Shah following his testimony admitting that the new mood on Capitol Hill was making for a "difficult situation" - but that the Administration remained steadfast in allowing Iran to determine its own defence needs. Kissinger reassured that he "would continue to work hard on the matter". ${ }^{33}$

The high level of scrutiny within the Congress did not stop the flow of military purchases. A comparatively lower-order pair of sales of 222 Harpoon anti-ship missiles and 39 Bell utility helicopters totalling US $\$ 207$ million got approval in August $1975 .{ }^{34}$ In the following three months, further sales of over US $\$ 70$ million won authorisation, including ground radar equipment and a pair of P-3F surveillance aircraft. ${ }^{35}$ Hence, despite the high level of scrutiny, Congress remained outwardly co-operative to the regular flow of arms to Iran, not yet wielding its veto power over arms sales packages in excess of US\$25 million. Absent the full understanding for selling these arms and the deeper arrangements at play, Congress had elected - at least for now - to allow a range of non-controversial sales to continue rather than risk upsetting an important allied relationship.

The culmination of Kissinger's actions vis-à-vis Congress would actually manifest some time later during the Democrat Jimmy Carter's first year in the White House in 1977 following his defeat of Ford in the 1976 election. By that point, Congress had grown tired of the pattern of affairs and decided to reject a major Iran arms sale that had its roots in the Nixon-Ford years. When the Shah eventually placed an order in 1977 for a fleet of AWACS radar aircraft, both Houses of Congress rejected the sale and made public the extent of their frustration with regular lack of consultation in Iranian-American arms sales. Although extensive lobbying by Carter allowed the sale eventually to clear Congress on a second reading, the long drawn affair and public hearings demonstrated the level of pent up frustration visible on Capitol Hill. For Senator Hubert H. Humphrey, the unsuccessful Democratic presidential nominee in 1968, a culture had emerged in the executive of treating arms sales "as if we were selling televisions and refrigerators and washing machines". ${ }^{36}$ To remedy this situation, Congress desired a fuller consultation role in examining arms deals before they were agreed and simply rubberstamped. A Republican, Senator Clifford P. Case, addressed this problem acutely, using the AWACS sale as an example:

We are not really going to be able to review something if the Shah of Iran has already been told he is going to get it 3 or 4 years ago and if he has made all his own plans and staked his prestige in part on the promise that he is going to get it. 
Our relations with Iran are going to suffer if we exercise effectively what the public expects us to exercise; namely, a normal oversight function. ${ }^{37}$

With all this to mind, it is not surprising that Congress drew a line over arming Iran.

What may be surprising is that it took until 1977 to do so effectively. This delay is no doubt due to the effectiveness of Nixon, Ford and especially Kissinger's deft manoeuvres. Additionally, although the evasive tactics and denial of information to Congress had allowed progress in the mid-1970s, it did have the longer term effect of destabilising not only Iranian-American relations, but also the political fate of the Shah, who began to lose his grip on power as domestic opposition hardened through 1977 and 1978. In the words of Cyrus Vance, Carter's secretary of state, when reflecting on the Iran-AWACS-Congress debacle: "The effect of this summer-long fight was, perversely, to shake the Shah's confidence in the United States as a dependable ally. He missed the more open access to U.S. Military equipment he had enjoyed in the early 1970s, and he resented the public criticism". ${ }^{38}$

\section{The Schlesinger Challenge}

Regular concerns within the Department of Defense over the level of arms sold to Iran had surfaced as early as late 1973. They were first evident at the staffer level, before closely aligning with the views of the secretary of Defense, Schlesinger. Schlesinger eventually commissioned a wide-ranging Department of Defense-led study into Iran arms policies in early 1975 - a study never fully consummated during the life of the Administration. Schlesinger took the earliest opportunity to summarise its draft findings directly to the president in early May 1975 with a cautionary memorandum. He warned that significant doubt existed over whether the open-ended military commitment to Iran was in America's best interests due to a growing divergence of American policies and Iranian behaviour. ${ }^{39}$ Schlesinger reported that Iran's defence spending had risen to 15.2 percent of GDP and experienced a 15-fold increase in expenditure from 1968 to 1975. With that context in mind, Schlesinger set out two major problem areas. First, the "lack of training or even trainable Iranian manpower ... plus delays in the huge construction programs required to provide supporting facilities for the weapons and equipment being obtained from abroad" ${ }^{40}$ Second:

Frankly, the US itself would find it extremely difficult to handle expansion programs of this size and speed; the Iranians cannot do it. The military supply system is a shambles. There is no delegation of authority, military pay and housing lags behind the civil sector, incompetence and corruption are endemic, and there is no prospect that the Iranian forces will be in respectable fighting shape for years to come.

American personnel deployed in Iran, both military and civilians - the latter comprised of large numbers of ex-American forces - was to grow to 17,000 in 1976, a rise of over 40 percent from 1975 levels. The study predicted that numbers would rise to 76,000 in 1980 - a number that would pose "a significant drain" on American military and technical resources. ${ }^{41}$ The outlook for Iranian-American relations in the second half of the 1970s was hence - according to Schlesinger - not the rosy picture envisioned by Kissinger 
and Nixon earlier in the decade; and there was a very real possibility that Nixon's blank cheque would need re-thinking due to Congressional pressures. Schlesinger requested using his appraisal of the Iran situation as the basis for a National Security Study Memorandum [NSSM] on Iran to envision better the challenges laying ahead. Two weeks later, Kissinger responded by initiating NSSM 223, calling for a long-term review of the logic and purpose of American policy on arms transfers in general, not a detailed study of Iranian-American arms policy. ${ }^{42}$ In that sense, Kissinger's control over the policy process allowed him to redirect and dilute Schlesinger's concerns to insulate Iran and the agreements made in May 1972 - of which Kissinger remained a steadfast advocate.

Schlesinger's position on Iran seemed at odds with his established reputation as a relative hawk who advocated enhanced American military power and a harder line on détente with the Soviet Union. ${ }^{43}$ The latter was vocalised via the so-called "Schlesinger doctrine" that recommended a deepened and expanded American nuclear deterrence posture to facilitate a more substantial commitment to American allies in sensitive areas, particularly Europe. ${ }^{44}$ Further, during the 1973 Yom Kippur War, Schlesinger had supported the American airlifts of arms to Israel because it demonstrated that the Untied States did not intend to abandon its allies in the Middle East. ${ }^{45}$ Adding a further layer of mysteriousness into Schlesinger's Iran-arms warning, the draft report on Iran to which he had referred in May was somewhat different in its conclusions than he had presented to Ford - as evidenced with its publication in full on 5 August 1975. The study actually concluded that continuing the military relationship with Iran was important, with no major changes advisable beyond a revision of "certain practical problems" that could be remedied by better implementation, oversight, and planning by both the American military and Iran. ${ }^{46}$ Hence, Schlesinger had pre-emptively politicised the report in an attempt to influence Ford, counter Kissinger's steadfast pro-Shah advocacy, and attempt to introduce some moderation into Iran arms policy.

Despite his larger strategic concerns, Schlesinger's position on Iran was actually a constant. From the outset of his tenure at the Pentagon in July 1973, he had expressed disquiet at the American arms relationship with the Shah, an impression that only deepened following each of several meetings he had held with the Shah during 1973-1975. Although always lending Iran "a sympathetic ear", to quote the Shah, ${ }^{47}$ Schlesinger believed that the extent of the arms relationship was irresponsible, disproportionate, and would erode the international prestige of the Department of Defense as a reliable military partner. ${ }^{48}$ Acting on his concerns, Schlesinger despatched a former colleague and retired Army colonel, Richard Hallock, to Tehran in September 1973 to act as his unofficial eyes on the ground. Much to Schlesinger's disapproval, Hallock simultaneously accepted a multi-million-dollar consultancy contract with the Shah. This placed Hallock in a position in which he was essentially advocating for the Shah on military matters whilst also working as an independent advisor for the Pentagon. Worse still, Hallock was also consulting for various arms suppliers. ${ }^{49}$ As a result, Schlesinger did not get the independent advice he had anticipated as Hallock essentially joined the burgeoning pro-Iran arms camp in Tehran 
and, in doing so, used his inside knowledge of the American military procurement system to bargain for millions of dollars worth of discounts for the Shah's prospective purchases..$^{50}$

Hallock supplemented his own advisory role by assisting the Iranians by bringing in a greater number of independent military experts; this balanced against the official Pentagon-staffed American Military Affairs Advisory Group. General Hassan Toufanian, the longstanding Iranian vice-minister of War for Armaments, later described Hallock as "a force at the Pentagon resembling Oliver North in the [Ronald Reagan] White House in later years". ${ }^{51}$ Whilst the Iranians were understandably very happy with Hallock, the Defense Department's Criminal Division dismissed him in mid-1975, which raised the alarm of the Congress that investigated Hallock the following year..$^{52}$

The Hallock affair was but the latest in a familiar pattern of American diplomats, advisers, politicians, and officials arriving in Iran and quickly succumbing to "Tehranitis", best described as an affliction that struck those present with a noticeably unbalanced pro-Shah disposition. The cause of this strange affliction may have been personal political gain, the distortion effect caused by Cold War geopolitics, greed, infatuation, or awe for the Shah's personality and grand designs - or a blend of any of the aforementioned. Successive American ambassadors to Iran exhibited strong signs of the affliction. Armin Meyer and Douglas MacArthur established the trend through the mid-late 1960s and early 1970s, becoming consistent advocates for the Shah and his arms ambitions during their time in Tehran. Richard Helms became the most vocal pro-Shah ambassador of all, taking his cues from the Nixon-Kissinger encounter in Tehran in May 1972, which effectively established Tehranitis as American national policy through the highly unusual military relationship it initiated. The concept of Tehranitis appears as the sharper edge of what James A. Bill dubbed "Pahlavism", which accounts for a four-decade long series of personal and political ties between the Shah, his regime, and American political and business elites. ${ }^{53}$

Whilst Schlesinger, a senior Administration figure notable for his lack of Tehranitis, had succeeded in opening up a review of American arms policies, completing NSSM 223 did not occur until 4 June 1976, almost one year behind schedule. The glacial pace was a product of Kissinger's deft manoeuvring, ensuring that the relationship with Shah - which had his unwavering personal advocacy - was not interrupted. ${ }^{54}$ In the interim, much had changed in the Administration. Schlesinger had become increasingly adversarial with Kissinger ${ }^{55}$ he also had never been popular with Ford, uncomfortable with Schlesinger's professorial, often arrogant, personality and the disruption his rivalry with Kissinger caused within the Administration. ${ }^{56}$ Suggesting that Schlesinger often failed to carry out Ford's orders. James Cannon observed, "As time went on, Ford's resentment grew; he counted the occasions when Schlesinger had been insubordinate". Ford would admit to Cannon, "It came to me one day. I had gotten fed up with the conflict between Schlesinger and Kissinger. Their continuous bickering and disagreement disrupted the way I thought defense and foreign policy ought to operate together". ${ }^{57}$ As Ford described to Kissinger, 
Jim's fight is not with you but with me. He thinks I am stupid, and he believes you are running me, which he resents. This conflict will not end until I either fire Jim or make him believe he is running me. ${ }^{58}$

Ford eventually fired Schlesinger and replaced him with his trusted aide and close friend, Donald Rumsfeld, who was previously Ford's chief of staff and American ambassador to NATO. In turn, Rumsfeld's protégé, Dick Cheney, replaced him as chief of staff. At the same time, Ford promoted Scowcroft as national security advisor rather than have him continue to deputise for Kissinger, who remained secretary of state. The reshuffle was an attempt by Ford to put his own stamp on his foreign policy machine and, in Scowcroft's case, deflect persistent accusations that Kissinger's power had become excessive. ${ }^{59}$ In reality, Kissinger retained his influence in the White House and his mastery over the exercise of foreign policy, relying on Scowcroft as a trusted ally who ran the NSC as a co-ordination mechanism, rather than as a proactive policy entrepreneur as it had been during Kissinger's tenure. ${ }^{60}$

\section{Continuity in a Testing Climate}

When NSSM 223 did finally arrive, it set out a Department of Defense position that did not reflect Schlesinger's alarmism and had evolved yet further from the August 1975 study on Iran. Whilst addressing Iran's arms absorption and integration problems, mention of Iran was infrequent due to Kissinger's re-focusing of the study to be broad rather than particular. With that factor in mind, it is fair to assume that the general recommendations made in NSSM 223 represented the desired state of affairs with Iran as America's largest arms customer. Although it would be inaccurate to accuse Rumsfeld of being prey to Tehranitis, he did not share Schlesinger's alarmism either. Rumsfeld led the Department of Defense to conclude in its report for NSSM 223 that the case for a policy change on arms was "exaggerated". ${ }^{61}$ Instead, the Department advocated for what it called a "tuning" of existing processes to incorporate clearer guidelines for sales and a more active inter-departmental oversight of arms transfers. ${ }^{62}$ There is a peppering of discrepancies in the extant literature over this issue. It occurs with an often-held assumption - based solely upon observational accounts - that Rumsfeld maintained Schlesinger's concerns, reflected by a consensus within the Department of Defense. ${ }^{63}$ Whilst this may be true in the sense that the problems in Iran did not blinker the Pentagon, the results of NSSM 223 speak clearly enough to render these judgments inaccurate.

The real lingering voice for caution in the Pentagon following Schlesinger's departure was the deputy secretary, Robert Ellsworth, ironically appointed by Rumsfeld. In February 1976, Ellsworth had petitioned a gamut of senior defence-oriented Administration officials, "It is absolutely essential that Iranian requests, and the scope and character of our own potential involvement, be rigorously examined to insure that we and the Iranians both understand the ramifications of any given case or project". ${ }^{64} \mathrm{He}$ continued, "In today's environment it is all the more important that DOD consideration of Iranian requests be 
most thorough and that we avoid any advocacy role on the part of U.S. officials associated with Iranian programs".

Ellsworth's efforts earned him the accusation, through Kissinger, of being part of a "viciously anti-Iranian" cabal. That cabal also featured the Treasury secretary, William Simon, who had built a reputation of speaking out publicly and privately against the Shah due to Tehran's aggressive oil price policies that culminated in the quadrupling of petroleum prices during the oil shocks of 1973-1974. ${ }^{65}$ The Shah needed enhanced oil revenues for his arms purchases. Therefore, in a way - although perhaps perverse when factoring in the effects on the American economy - Nixon had instructed Simon and others like him not to question the Shah's motives in public. Nixon and Kissinger both felt, privately, that the price increases were inevitable and that the security relationship with the Shah was more important in the long run. ${ }^{66}$ In the end, regarding the Department of Defense saga in this issue, Kissinger's influence over Ford was sufficient to impress upon the president the importance of maintaining the status quo with Iran due to its centrality in the Administration's Gulf policy package of outsourcing containment by means of arms sales. In turn, Ford made it at least implicitly clear to Rumsfeld on several occasions, and explicitly on at least one occasion, the emphasis he would like the Department of Defense to stress on Iran, which mirrored that of Kissinger. ${ }^{67}$

Whilst Rumsfeld was able to quell Ellsworth, the State Department and the Arms Control and Disarmament Agency [ACDA] made a case with NSSM 223 that arms policies in certain cases needed clear changes to reflect the need for increased caution in military sales. The positions advocated were far short of any dramatic change in policy and represented a desire for more oversight rather than a serious re-think. Both agencies pushed for the creation of a new board representing each department and agency involved in arms transfers. It would become complete with a supporting co-ordinating group to institutionalise both the exercise and the subsequent oversight of all arms transfers including commercial sales and co-production agreements. ${ }^{68}$

Despite the calls from the State Department and the ACDA for change beyond "tuning", the NSSM study inspired no great Administration attention. It lingered in "bureaucratic limbo" as the presidential election campaign gathered pace in mid-1976. ${ }^{69}$ In that sense, Kissinger's delaying and re-focusing of the study, together with his persuasiveness in conversation with Ford, succeeded in taking the issue of revising Iran-arms policy off the agenda. It occurred despite the outwardly confusing result of Kissinger's State Department actually advocating for a structural change in policy of sorts. In that sense, inferences are possible that the recommendations were general, not specific to Iran - Kissinger, with Ford's support, would have acted to exempt or privilege Iran from any such interdepartmental oversight if the consolidating the study into a corresponding policy pronouncement. Yet, it never happened.

Ford's personal approval - on Kissinger and Rumsfeld's recommendation - that Iran be permitted a US\$3.8 billion purchase contract for 160 F-16 fighters in September 1976 
serves as clear confirmation of the president's disposition. ${ }^{70}$ The F-16s were gradually to replace the Shah's ageing F-4 and F-5 fleets. Ford's approval for the large purchase assuredly would raise a red flag on Capitol Hill. In March 1976, Congress had exercised its new statutory powers to hold up a comparatively minor sale of C-130 transport aircraft to Egypt. This action subsequently raised alarm in Tehran that Iran might be next in the Congressional firing line. ${ }^{71}$ By summer 1976, it had become apparent to Kissinger that there was a clear "anti-arms-sales binge on the Hill". ${ }^{72}$ Not just Congressional concern over arms sales that had been building since 1973 drove this sentiment. Inaccurate reporting in the American press sparked Congressional alarm over a new US\$10 billion arms agreement with Iran, as part of a larger US $\$ 50$ billion commercial deal. ${ }^{73}$ The US $\$ 10$ billion figure was actually largely comprised of credit re-payments, due over the coming five years; hence, it was for deals already done, such as Iran's purchase of 80 F-14 jets. The remaining US $\$ 40$ billion was largely accountable to an as-yet unsigned and contentious Iranian-American commercial nuclear energy deal, which was undergoing protracted negotiations due to enhanced non-proliferation concerns in the United States following India's nuclear test in 1973. It stalled progress here - and with various other formative arms deals and infrastructure projects. ${ }^{74}$ The nature of the media rumours sent the Shah into a fit of paranoia that certain interests, including Israel, were lobbying against Iran in Washington and leaking false information. ${ }^{75}$

With high sensitivity in mind, the official Congressional notification of the F-16 sale became re-scheduled from August to late September so that deliberations would not be possible until early 1977 due to Congress adjourning for the election season. It was a Kissingerbacked scheme. The hope was that the Congress might be more favourable post-election should the results strengthen the position of Ford and/or the Republican Party. ${ }^{76}$ With US $\$ 570$ million in additional sales to Iran of spare parts, artillery, ammunition, and missiles already being prepared to send to Congress before the cut-off date, adding the F-16 would diminish the likelihood of those comparatively small sales successfully clearing any scrutiny. ${ }^{77}$

A media offensive by the Shah amplified news of the F-16 sale in late 1976 in which he gave numerous interviews and speeches regarding his military plans. Both Houses of Congress sought to utilise what remaining time was available before the November election to debate the implications of the sale. The Shah's public admission that an initial sale of $160 \mathrm{~F}-16$ s would follow with a large F-18 order and 140 more F-16s quickly overshadowed the debate. The background to this situation reflected a time of high strain over arms sales between the Congress and the Ford Administration. In a 16 September hearing of the Sub-committee on Foreign Assistance of the Senate Committee on Foreign Relations, Humphrey delivered an angry riposte toward the Executive: "Today I regret to report that the performance of the Departments of Defense and State in responding to our requests for information during this crucial period has been deplorable". ${ }^{78}$ The problem was an old one: Kissinger's continued refusal to authorise the release of various arms documents that the Congress had requested. Humphrey noted that the material begrudgingly sent was "of a highly superficial nature and cannot be regarded as a serious 
response to the committee's inquiries", before adding; "the requests cannot be pushed aside, voided. That day is over" ${ }^{79}$

Setting Kissinger's manoeuvres aside, two underlying problems with the current state of affairs stirred Congressional frustrations. The first involved what Humphrey described as that culture of treating arms sales as a trivial matter rather than one with serious ramifications. Second, a thinly-veiled Administration desire to neuter the effectiveness of Congressional oversight on arms had led to abuse of the process in the form of not only withholding requests for documents, but also through the dumping of multiple arms sales all at once. Forty such arms sale notifications totalling US\$6 billion went to the Congress for approval in the first days of September 1976 alone. It was impossible for Congress to assess these properly; hence, as the Ford Administration entered its twilight, there was a sense that the story of increasing Congressional oversight respecting arms sales had not yet reached its end.

Congress was not the only place where frustration with Iran's F-16 purchase was evident. There was also a basic uncertainty over the actual cost of the deal, which caused further stalling throughout September. In an exploratory meeting with the Shah in summer 1976, General Dynamics - the manufacturer of the F-16 - had estimated that the $300 \mathrm{~F}-16 \mathrm{~s}$ that the Shah required would cost Iran US\$2.14 billion. Yet, by the time that the Pentagon had formally assessed and costed the programme under the Foreign Military Sales credit framework, the price had spiralled to US $\$ 3.8$ billion for just 160 jets. Finding the underlying cause of the "muddle", NSC staffer Clinton E. Granger sought answers from the Pentagon. He then explained to Scowcroft that the original estimate by General Dynamics did not take into account start up costs, spares, support, inflation, and infrastructure costs. Additionally, it contained various other "erroneous assumptions" that did not account for modifications and variables that the sale would necessitate - such as the alteration of certain classified technology that needing removal from export models. ${ }^{80}$ Scowcroft returned Clifford's memorandum with the annotated header: "Incredible! And unacceptable", before adding in a further annotation, "how can this be?"81

Reacting to an essentially three-fold increase in the original price of the F-16, the Shah was understandably mystified. Additionally, he received evidence from an unnamed British source who claimed that the price rises were a deliberate Pentagon strategy to overcharge Iran, as Asadollah Alam, a minister at the royal court, paraphrased, "appropriate what little remains of our oil revenue". ${ }^{82}$ Alam's comment was related to the fact that the Shah's original plan was to part-pay for the F-16 with an oil barter agreement - an idea that had been on the table for over a year in one capacity or another. Broad opposition to the oilbarter was already in place across the Administration. An NSC memorandum condensed opposition from the Council of Economic Advisers, the departments of Defense and State, and the Office of Management and Budget for Kissinger when the pitching the idea to the Shah in 1975:

For 500,000 barrels of oil per day out of our total consumption of roughly $18,000,000$ bpd you are, in short, running a major policy and personal risk by 
advocating this proposal. The profound changes called for in the way the US does business and conducts its financial relations holds virtually no hope that the plan could succeed and will expose you to the worst sort of criticism. ${ }^{83}$

The oil for arms deal remained frustratingly out of reach in Washington, despite strong advocacy from Kissinger, due to the same co-ordination and implementation difficulties pointed out when first raising the idea. ${ }^{84}$ Inflation and rises in development and manufacturing costs had already led to over US\$1 billion in price increases of other equipment that Iran had previously commissioned. ${ }^{85}$ Such occurrences were part of the procurement process and were somewhat built into contracts. Yet, the Shah did have a legitimate concern that increases were beginning to spiral beyond mutually accepted projections. Scowcroft had previously raised the issue of the unacceptability over the lack of Pentagon influence over producer price increases in November 1975. At that time, he had suggested that Rumsfeld devise a system to anticipate future price problems and communicate those clearly to the Shah, thereby reducing friction when prices did go up. ${ }^{86}$ Clearly, this system was not yet working satisfactorily.

By mid-September 1976, the signs were clear that although the Administration was apologetic over the F-16 price discrepancy, the final price was accurate. With no other option short of scrapping the deal, the Shah's overriding desire to complete the next phase of his grand military strategy led him to accepta credit purchase for the full revised US $\$ 3.8$ billion F-16 deal on 13 September. ${ }^{87}$ The Shah quickly dashed any inkling that the threefold increase in cost would lead to some future restraint; he ordered 140 more F-16s on 1 October, making up his original figure of 300 - all of which would have to be passed through the Congress and rubber stamped by whichever candidate won the presidential election. ${ }^{88}$ On the same day, he also formally requested $250 \mathrm{~F}-18 \mathrm{Ls}$, with a provisional price for that deal alone in the region of US $\$ 5-6$ billion..$^{89}$ The F-18L was a multi-role fighter jet adapted for land use under development for export customers only. It was derived from the Navy's F-18 programme that had been developed as a more substantial alternative to the F-16 lightweight fighter, which the Navy had regarded as insufficient for its needs. Once again, the Shah envisioned payment for the F-18L in long term oil barter arrangements - an idea he seemed persistent in raising from the dead, despite such an arrangement remaining highly unlikely as Scowcroft reaffirmed in late October. ${ }^{90}$

When adding the multiple hundreds of F-16s and F-18Ls to the $80 \mathrm{~F}-14 \mathrm{~s}$ the Shah had already purchased - should those additional sales go ahead - the Shah was in the process of appropriating one of the most advanced air forces in the world in just a few short years. The fact that these deals remained pending due to the 1976 presidential election is beside the point. The climate for multi-billion dollar annual arms sales was still in place throughout the Ford years - in spite of the various obstacles. That the Shah felt he could confidently advance plans for the next step in his military revolution is testimony to this fact.

\section{Conclusion}


When Ford decided to maintain and deepen arms relations with Iran, he cemented a momentum that became near impossible for a successor to break, continuing the policy of his predecessor. Rumsfeld's appointment as secretary of Defense was the tokenistic end of what had essentially been a small Iran-arms revisionist cabal in the Ford Administration led by Schlesinger, sacked by Ford, Simon, marginalised by Nixon and Kissinger, and Ellsworth, overruled by Rumsfeld. The American approach to Iran formulated by Nixon and consummated following the 1972 meeting in Tehran by this point transcended Nixon, overcame resistance in Washington, and for better or worse had become received wisdom in American foreign policy. Ford maintained executive primacy over arms sales despite the rise in Congressional power watermarked by the twin peaks of Nixon's resignation and passage of the Nelson-Bingham amendment. A culture of secrecy by the executive met exploratory Congressional enquiries into the abnormally large volume of arms sales to Iran, which served to dilute Congressional effectiveness. The result was a Congress systematically excluded from playing a role in Iranian-American arms sales policy. And arms sales with Iran continued apace.

From the beginning of the arms relationship with the United States in the 1950s, when Iran was a low order military aid recipient, the Shah had understood that executive advocacy was the most effective means of achieving his arms needs. Whilst the general climate was building up to a change through the mid-1970s, that assessment remained accurate throughout the Ford years. Although Ford's authority would be consistently challenged by a Congress seeking to claw back some of its authority in the relationship between the executive and the legislature, ultimately the need to support allies in the Middle East against the threat of the Soviet Union, even during a time of détente, remained paramount. As such, continuing major arms sales to Iran seemed perfectly logical to the Administration, despite the misgivings of a small minority. The policy continued under Carter until the revolution of 1979 ended any influence America might have in Iran.

\section{Notes on contributors}

Stephen McGlinchey is a senior lecturer in International Relations at the University of the West of England, Bristol and editor-in-chief of E-International Relations (www.EIR.info). His most recent book is US Arms Policies Towards the Shah's Iran (2014).

Andrew Moran is an associate professor of International Relations and a university teaching fellow at London Metropolitan University. He has contributed to scholarly journals such as Presidential Studies Quarterly, White House Studies, The Amicus Journal, and Democratization (for which he was Book Reviews Editor for five years) and has appeared on BBC News 24, CNN, Voice of Russia Radio, and Bloomberg TV. He has also contributed to a variety of books on international security studies, United States politics, and the presidency of Barack Obama.

\section{Notes}


${ }^{1}$ See John Robert Greene, The Presidency of Gerald R. Ford (Lawrence, KS, 1995), 190-93; George C. Herring, From Colony to Superpower: U.S. Foreign Relations Since 1776 (Oxford, 2008), 814-18; Yanek Mieczkowski, Gerald Ford and the Challenges of the 1970s (Lexington, KY, 2005); A. James Reichley, Conservatives in an Age of Change: The Nixon and Ford Administrations (Washington, DC, 1981); James Cannon, Gerald R. Ford: An Honorable Life (Ann Arbor, MI, 2013)

${ }^{2}$ For a representative example relegating the Ford Administration to an infrequent footnote, see Gholam Reza Afkhami, The Life and Times of the Shah (Berkeley, CA, 2009); James A. Bill, The Eagle and the Lion: The Tragedy of American-Iranian Relations (New Haven, CT, 1988); Richard Cottam, Iran and the United States: A Cold War Case Study (Pittsburgh, PS, 1988); Douglas Little, American Orientalism: The United States and the Middle East since 1945 Chapel Hill, NC, 2008); David F. Schmitz, The United States and Right Wing Dictatorships, 1965-1989 (Cambridge, 2006). Also see Michael A. Palmer, Guardians of the Gulf: A History of America's Expanding Role in the Persian Gulf (NY, 1992), 85-112; Steven A. Yetiv, The Absence of Grand Strategy: The United States in the Persian Gulf, 1972 -2005 (Baltimore, MD, 2008), 28-42.

3 See Stephen McGlinchey, "Richard Nixon's Road to Tehran: The Making of the U.S.-Iran Arms Agreement of May 1972", Diplomatic History, 37/4(2013); Stephen McGlinchey, US Arms Policies Towards the Shah's Iran (Abingdon, 2014), 61-94.

${ }^{4}$ See Reichley, Age of Change, 281-83; Brent Scowcroft, "Ford as President and His Foreign Policy", in Kenneth W. Thompson, ed., The Ford Presidency: Twenty-Two Intimate Perspectives of Gerald R. Ford (Boston, MA, 1988), 310-11.

${ }^{5}$ Public Papers of the President. Gerald R. Ford: 1974 . . . August 9 to December 31, 1974 (Ann Arbor, MI, 2005), 9.

${ }^{6}$ Max Frieders dorf, interview with the author, 25 October 1994.

${ }^{7}$ Arthur M. Schlesinger, The Imperial Presidency (NY, 1974).

${ }^{8}$ Gerald R. Ford, A Time to Heal: The Autobiography ofGerald R. Ford (NY, 1979), 119-222.

${ }^{9}$ Ibid., 129.

10 Ibid.

${ }^{11}$ Ibid. Unlike his multiple advocacy approach to economic policy, Ford centralised the management of foreign policy.

12 Ibid, 199.

${ }^{13}$ Cannon, Ford, 275

14 Helms to Maury, 31 October 1974, Hoffman [Martin R. Hoffman Papers 1971-1977, Gerald Ford Presidential Library, Ann Arbor, MI] Subject File Iran Box 19 Folder Iran Military Sales and Assistance, 1972-1975.

15 "Visit of J. Norvill Jones and George W. Ashworth" - marked as "State POL", no other identifiers. This seems to be a facsimile sent from the State Department to Hoffman [general counsel, Department of Defense], 31 October 1974, Hoffman Subject File, Iran. Box 19. Folder: Iran Military Sales and Assistance, 1972-1975. ${ }^{16}$ See Helms to Maury, 31 October 1974, Ibid.

${ }^{17}$ Memorandum of Conversation with Kissinger, Schlesinger and Scowcroft, 14 November 1974. GFL NSA [National Security Agency Files, Gerald Ford Presidential Library, Ann Arbor, MI] Memcons Scowcroft File. 18 See McGlinchey, US Arms Policies, 7-61.

19 The documents at the forefront of the Congressional enquiries were two memoranda, dated June 151972 , and July 25 1972; both titled "Follow-up on the President's Talk with the Shah of Iran". Fulbright made his request via Fulbright to Kis singer, 12 November 1974, all GFL [Gerald Ford Presidential Library, Ann Arbor, MI] Presidential Country Files India-Iran Box 12.

${ }^{20}$ Long to Kissinger, 16 October 1974, Ibid.

${ }^{21}$ Kennedy and Oakley memorandum for Kissinger, 13 December 1974, Ibid.

22 Kis singer handwritten notes on Ibid.

23 See Ingersoll memorandum to Kissinger, 5 December 1974, Ibid.

${ }^{24}$ Kissinger, quoted from speech to World Affairs Council in late January 1975, in The Bulletin (25 January 1975): $\quad$ http://news.google.com/newspapers?nid=1243\&dat= 19750125\&id=r2RYAAAAIBAJ\&sjid=xvcDAAAAIBAJ\&pg=1357,1195995.

${ }^{25}$ David F. Schmitz, "Senator Frank Church, the Ford Administration, and the Challenges of Post-Vietnam Foreign Policy”, Peace \& Change,21/4(1996), 443. 
${ }^{26}$ See NSC memorandum, "Congressional Requests for 1972 Memoranda on Arms Sales to Iran", 10 February 1975, GFL Presidential Country Files India-Iran Box 12; Davis memorandum to Buchen, 9 June 1975, GFL White House Central Files, Subject File Box 23: FO 3-2/CO 55-CO 70.

27 Gerald Ford, "Statement on Signing the Foreign Assistance Act of 1974", 30 December 1974, The American Presidency Project: http://www.presidency.ucsb.edu/ws/index. php?pid=4660\#axzzlf2NEDtPT.

${ }^{28}$ Committee on International Relations Report, United States Arms Sales to the Persian Gulf: Report of a Study Mission to Iran, Kuwait and Saudi Arabia, May 22-31, 1975 (Washington, DC, 1976).

${ }^{29}$ See http://www2.gwu.edu/ nsarchiv/nukevault/ebb268/index.htm.

${ }^{30}$ The Persian Gulf, 1975: The Continuing Debate on Arms Sales, Hearings before the Special Subcommittee on Investigations of the Committee on International Relations: June 10, 18, 24, and July 291975 (Washington, DC, 1975).

${ }^{31}$ Foreign Assistance Authorization: Arms Sales Issues - Hearings before the Subcommittee on Foreign Assistance of the Committee on Foreign Relations, June 17 and 18, November 19 and 21, and December 4 and 5, 1975 (Washington, DC, 1976).

32 Kissinger telegram to Helms, 25 July 1975, GFL Country File Iran (4) Box 13.

${ }^{33}$ Ibid.

${ }^{34}$ See Granger memoranda to Scowcroft, 19 and 26 August 1975, Ibid.

${ }^{35}$ See Granger memoranda to Scowcroft, 9 September and 31 October 1975, Ibid.

${ }^{36}$ Statement by Humphrey, 16 September 1976, in U.S. Arms Sales Policy: Hearings before the Committee on Foreign Relations and the Subcommittee on Foreign Assistance, September 16, 21, and 24, 1976 (Washington DC, 1977).

37 Testimony of Case, 16 September 1976, Ibid.

${ }^{38}$ Cyrus Vance, Hard Choices: Critical Years in American Foreign Policy (NY, 1983), 321.

${ }^{39}$ Schlesinger memorandum, "DOD Activities and Interests in Iran", to Ford, 5 May 1975. DNSA [Digital National Security Archive] PR01303.

${ }^{40}$ Ibid. [emphasis author's].

${ }^{41}$ Ibid.

42 NSSM 223, "Review of U.S. Policy on Arms Transfers", 19 May 1975: http://www.ford.utexas.edu/library/document/nsdmnssm/nssm223a.htm.

${ }^{43}$ See Greene, Ford, 121-22; Henry Kissinger, Years of Renewal (NY, 1999), 176-80. For a direct incident where Schlesinger's détente opinions caused friction in the White House, see Scowcroft memorandum to Kissinger, 15 April 1975, GFL NSA Presidential Agency File Box 7.

${ }^{44}$ See David S. Yost, "The US Debate on NATO Nuclear Deterrence”, International Affairs, 87/6(2011), 1405.

${ }^{45}$ See Little, American Orientalism, 106-07.

46 "DOD Activities and Interests in Iran", 5 August 1975, DNSA: IR00980.

${ }^{47}$ Asadollah Alam, The Shah and I: The Confidential Diary ofIran's Royal Court, 1969-1977 (London, 1991), 450.

${ }^{48}$ See Gary Sick, All Fall Down: America's Tragic Encounter with Iran (NY, 1985), 17-18. Sick and Schlesinger both served in the Carter Administration, and Sick based his observations on personalencounters with Schlesinger over the subject of Iran in 1978.

${ }^{49}$ See, Gholam Reza Afkhami, The Life and Times of the Shah,314-15; Sick, All Fall Down, 17-21.

${ }^{50}$ Mohammed Reza Pahlavi, Answer to History (NY, 1980), 197.

${ }^{51}$ Gholam Reza Afkhami, The Life and Times of the Shah,(Berkeley, CA, 2009), 214.

${ }^{52}$ See the "Iran Hallock, Richard" folder, Hoffman Subject File Box 18. Also see Barry Rubin, Paved with Good Intentions: The American Experience and Iran (NY, 1981), 164-65.

${ }^{53}$ Bill, Eagle and the Lion, 319-78.

${ }^{54}$ Sick, All Fall Down, 17-21.

${ }^{55}$ Kissinger, Years of Renewal, 178-81.

${ }^{56}$ Ford, Time to Heal, 324-25.

${ }^{57}$ Cannon, Ford, 379.

${ }^{58}$ Kissinger, Years of Renewal, 181-82 [emphasis in original].

${ }^{59}$ David Rothkopf, Running the World: The Inside Story of the National Security Council and the Architects of American Power (NY, 2005), 153. 
${ }^{60}$ See Ivo H. Daalder and I. M. Destler, In the Shadow of the Oval Office: Profiles of the National Security Advisers and the Presidents They Served - From JFK to George W. Bush (NY, 2009), 90-91, 259-61; Rothkopf, Running the World, 19-20.

${ }_{61}^{61}$ NSSM 223, "Review of US Policy on Arms Transfers", 4 June 1976, DNSA: 01394.

62 Ibid.

${ }^{63}$ See Andrew Scott Cooper, "Showdown at Doha: The Secret Oil Deal that Helped Sink the Shah of Iran", Middle East Journal, 62/4(208), 580-81; Richard T. Sale, "Arms Quarrels Strain US-Iran Ties”, Washington Post (13 May 1977). Known for his willingness to criticise government policy, Simon later said, "Politicians are all whores .... They are [only] interested in getting re-elected". William E. Simon, interview with the author, 16 May 1994.

${ }^{64}$ Ellsworth memorandum, "DOD Activities and Interests in Iran", 24 February 1976 addressed to the Secretaries of the Military Departments, the Chairman of the Joint Chiefs of Staff, the Director of Defense Research and Engineering, the Assistant Secretaries of Defense (and their assistants), the U.S. Defense Representative to Iran, the Director of Telecommunications and Command and Control Systems, and the Directors of Defense Agencies, DNSA: IR01020.

${ }^{65}$ Memorandum of conversation with Kissinger, Ford, and Scowcroft, 3 August 1976, GFL NSA Memoranda of Conversations Box 20.

${ }^{66}$ See Henry Kissinger, Years of Upheaval (Boston, MA, 1982), 858-966; "Energy: Countering the Oil Cartel", Time (25 November 1974). Also see Tore T. Petersen, Richard Nixon, Great Britain and the AngloAmerican Alignment in the Persian Gulf and Arabian Peninsula: Making Allies out of Clients (Brighton, 2009), 29-47; Richard C. Thornton, The Nixon-Kissinger Years: Reshaping American Foreign Policy (St Paul, MN, 2001), 302-13; Daniel Yergin, Prize: The Epic Quest for Oil, Money, and Power (NY, London, 1993), 613-44.

${ }^{67}$ Ford continually expressed agreement with Kissinger's position on the Shah. As late as August 1976, Ford continued personally to interject into Iran discussions by contacting Rumsfeld directly to express his wishes. See memorandum of conversation with Kissinger, Ford, and Scowcroft, 3 August 1976 GFL NSA Memoranda of Conversations Box 20.

${ }^{68}$ NSSM 223, "Review of US Policy on Arms Transfers", 4 June 1976, DNSA: 01394.

${ }^{69}$ See Rubin, Paved with Good Intentions, 170-71; Sick, All Fall Down, 20-21; memoranda between Oakley and Scowcroft, 13 August 1976, GFL Presidential Country Files for the Middle East and South Asia Box 2. Discussion of NSSM 223 still occurred at the working group level in December 1976; see Scowcroft memorandum to Kissinger, Rumsfeld, Bush, and the Director of the Arms Control and Disarmament Agency, 9 December 1976, GFL NSC Institutional Files 1974-1977 Box 35.

${ }^{70}$ See Davis memorandum to Howe, 13 September 1976, GFL White House Central Files Box 25 Subject File CO 68 Iran.

${ }^{71}$ Helms telegram to State Department, 29 March 1976, GFL Country File Iran-State Department Telegrams Box 14.

${ }^{72}$ Kissinger memorandum of conversation with Ford, Kissinger, and Scowcroft, 13 August 1976, GFL NSA Memoranda of Conversations Box 20.

73 "U.S. Support of Shah of Iran Reinforced by New Pledges during Kissinger's Visit", Wall Street Joumal (9 August 1976).

${ }^{74}$ Helms telegram to State Department, 26 August 1976, GFL Country File Iran-State Department Telegrams Box 14.

${ }^{75}$ Helms telegram to State Department, 25 September 1976, Ibid. Also see Alam, The Shah and I, 504, 515516.

${ }^{76}$ For the gradual decision-making process on this is sue, see Oakley memorandum to Scowcroft, 14 August 1976, State Department Action Memorandum, 13 August 1976, McCloskey and Atherton memorandum to Kissinger, 18 August, 1976, all GFL Presidential Country Files for the Middle East and South Asia Box 2; Helms telegram to State Department, 26 August 1976, GFL Country File Iran-State Department Telegrams Box 14.

${ }^{77}$ See Granger memorandum to Scowcroft, 13 August 1976, Granger memorandum to Hyland, 19 August 1976, both GFL Presidential Country Files For the Middle East and South Asia Box 2; Kissinger telegram to Helms, 24 August 1976, DNSA: IR01080.

${ }^{78}$ Statement by Humphrey, 16 September 1976, in U.S. Arms Sales Policy.

${ }^{79}$ Ibid.

${ }^{80}$ Granger memorandum to Scowcroft, 3 September 1976, GFL Presidential Country Files Iran Box 13. 
${ }^{81}$ See Scowcroft's handwritten annotations on the return copy of Ibid.

82 Alam, The Shah and I, 506-07.

${ }^{83}$ Hormats and Oakley memorandum to Kissinger, 6 June 1975, GFL Presidential Country Files Iran Box 13. For the continued problems over this deal, Hormats memorandum to Scowcroft, 14 January 1976, Ibid.

${ }^{84}$ See Zarb memorandum to Ford, 13 January 1976, Ibid.

${ }^{85}$ See the folder "Lightweight Fighters", Hoffman Papers Subject File Iran - Sparrow Box 20; Granger memorandum to Scowcroft, 21 January 1976, GFL Presidential Country Files Iran Box 13.

${ }^{86}$ Scowcroft memorandum to Rumsfeld, 24 November 1975, Ibid.

${ }^{87}$ Granger memorandum to Scowcroft, 13 September 1976, Ibid.

88 Point Paper, "Chronology of F-18L Program for Iran", nd, Ibid.

${ }^{89}$ Ibid.

${ }^{90}$ Scowcroft memorandum to Ford, 27 October 1976. GFL NSA Presidential Agency File Box 9. 